\title{
Germany plans new aid for scientists in east
}

Munich. Proposals for a new government research fund, intended to provide continued support for hundreds of senior eastGerman scientists who might otherwise lose their jobs next year when interim aid to east Germany comes to an end, are being drawn up the Wissenschaftsrat, Germany's science council.

The fund would be limited to scientists who rely on grants for their salaries proportionately there are more of these in the east than in the west. But the Wissenschaftsrat hopes that the proposed fund would also help to tackle the relative lack of competition for funds between researchers working in national research centres in west Germany.

The east German problem has more recent roots. After reunification in 1990, research institutes belonging to the East German Academy of Sciences were reviewed by the Wissenschaftsrat. Many were closed, and others were absorbed into the research organizations of West Germany, such as the Max Planck and Frauenhofer Societies.

But, at the Wissenschaftsrat's suggestion, the federal government also agreed to the creation of three new national research centres: the Max Delbrück Centre for Molecular Medicine in east Berlin, the Centre for Geophysics in Potsdam and the Centre for Environmental Research in Leipzig-Halle.
The government laid down conditions for the new national centres, hoping to avoid repeating past mistakes in the west. West German institutions have been criticized over the past decade for their inflexibility and variable research quality. Scientists have job security, and their research is funded fully by the government; as a result, there is no pressure to compete for outside grants with other German researchers.

The Wissenschaftsrat planned that the national research centres in the new Länder should rely much more heavily on shortterm competitive grants, with far fewer principal investigators benefiting from permanent posts than in the west. At the Max Delbrück centre, for example, founded in 1992 , it was planned that the basic budget would support 350 permanent positions, with an additional 250 posts funded by competitive grants (see Nature 360, 617; 1992).

Accepting that east German scientists were unlikely to succeed in obtaining significant grants immediately, the federal government created a temporary fund to supplement the basic budget of the research institutes set up in this way. In 1994 this money funded about 300 positions in the east, and in 1996 - the last transition year - around 100 will be funded.

But expectations that scientists would generate sufficient external funding to support themselves and their research by the time this money runs out now appear to have been too ambitious.

One problem is that funding agencies such as the Deutsche Forschungsgemeinschaft (DFG) do not in general cover the salaries of principal investigators, making it almost impossible for scientists on short-term contracts to lead their own research groups. Nor is industry a likely source of increased funds, as most industrial grants are for applied research, not basic.

Competition for all grants is particularly intense at present. The budget of the DFG has not increased in real terms for the last five years. But the pool of scientists competing for grants previously intended only for west Germany has increased following reunification and a special DFG fund for east Germany, already widely considered insufficient, ran out at the end of last year.

The prospects for scientists in the east are bleak. "Unless other means of funding are found, the continuation of successful projects is threatened, and entire research groups may have to be dissolved," says Klaus Fleischmann, executive secretary of the Arbeitsgemeinschaft der Grossforschungseinrichtungen, the umbrella organization for national research centres. Toni Feder

\section{Cell biology centre}

Paris. The Institut Curie in Paris, which has a long-running tradition of both supporting basic research and exploiting it directly to prevent, diagnose and treat cancer, is to set up a FFr150-million (US\$28-million) cellbiology centre next year.

The creation of the centre represents an unusual experiment for French science, in that the institute plans to reserve a quarter of posts for postdoctoral researchers on shortterm contracts. These researchers will be encouraged to create their own teams but take them elsewhere after five years.

The institute is situated in the Latin Quarter of Paris, combining at a single site a modern hospital - the Claudius Regaud hospital -- for cancer patients, and research departments in biology, medicine, physics and chemistry. These are linked by a 'technology transfer' corridor occupied by both researchers and clinicians.

The complex was established as the Institut Radium in 1909 by the University of Paris and the Institut Pasteur, with Marie Curie heading one of the first laboratories. In 1970, the Institut Radium was merged with the Curie Foundation to form the Curie Foundation-Institut Radium, later renamed the Institut Curie.

The FFr100-million construction costs of the new centre, due to be officially opened in October, and its FFr50 million of equipment, will be paid for by the institute, which is a private foundation with a budget that grew from FFr306.5 million in 1986 to FFr514 million in 1992 . The salaries of scientists working at the centre will be mainly paid either by public research organizations, such as the Centre National de la Recherche Scientifique (CNRS) and the biomedical research agency INSERM, or by grants from other research agencies.

The new centre will add 3,500 square metres to the existing 6,000 square-metre biology department and accommodate another 150 staff in addition to the 350 at present. The Subcellular Structure and Cellular Dynamics programme will be made up of 10 research groups headed by JeanPaul Thierry. This programme will be jointly funded by the CNRS and Institut Curie.

The centre will be headed by Daniel Louvard, director of biology at the institute. The novelty of the fixed-term contract arrangement stems from the fact that almost all working scientists in France are civil servants with life tenure. The government is reluctant to create a population of researchers on short- term contracts. But this has restricted the mobility of young researchers within France and the flow of talent into active research groups.

Louvard says he wants to create a system within France similar to that of the European Molecular Biology Laboratory (EMBL) at Heidelberg, Germany. Louvard himself was trained at EMBL, and later set up a laboratory at the Institut Pasteur in Paris.

Staff at the new institute will be employed on the understanding that they will

\section{IMAGE UNAVAILABLE FOR COPYRIGHT REASONS}

